\title{
Prevalence of deaf people who have a professional Argentine Sign Language interpreter during their children's medical consultations
}

\author{
Adrián M. Cutri, M.D., ${ }^{a}$ Fernando A. Torres, M.D., ${ }^{a}$ Prof. Claudio C. Riquelme \\ Prof. Norma B. Cabrera, ${ }^{b}$ Prof. Ricardo R. Sandoval, ${ }^{b}$ Prof. Silvia M. Vesconi, ${ }^{c}$ \\ Sandra Di Lalla, M.D. ${ }^{a}$ and Lorena Cordi, M.D. ${ }^{a}$
}

\section{ABSTRACT}

Introduction. In Argentina, hearing disability accounts for $18 \%$ of disabilities. Argentine Sign Language (ASL) is the communication system of choice used by deaf people (DP). An incorrect communication with physicians hampers the adequate provision of health care.

DP require a professional ASL interpreter (PASLI) in the context of health care provided to their children.

National Act no. 26378 stipulates the provision of a PASLI to facilitate access to public facilities. However, most DP neither have an interpreter nor know this right.

Objectives. To describe the prevalence of DP who have a PASLI present during their children's medical consultations and who know their right to access one at no charge.

Material and method. Approved and registered, descriptive, cross-sectional study with a structured, self-administered survey. Participants:DP whoknew ASL and had children aged 1 month to 18 years old. Outcome variables: to have a PASLI and to know the right to have one. Estimated sample size: 220. Convenience sampling selected from the Autonomous City of Buenos Aires and the province of Chaco. The prevalence and $95 \%$ confidence interval $(95 \% \mathrm{CI})$ were estimated.

Results. Two hundred and twenty-two surveys were analyzed. Age: $34.9 \pm 10.1$ years old. Among all participants, $15.3 \%$ (95\% CI:11.1-20.6) sometimes had a PASLI during their children's medical consultations. Also, 48.6\% (95\% CI: 42.155.1) knew their right to have one.

Conclusion. The prevalence of DP who had a PASLI present during their children's medical consultations was low. Less than a half knew their right to have one.

Key words: right to health, deafness, prevalence, sign language.

Funding:

This study was conducted in the framework of a scholarship granted by the Argentine Society of Pediatrics (Sociedad Argentina de Pediatría) in 2016.

Conflict of interest: None.

Received: 12-19-2017 Accepted: 2-26-2018

\section{INTRODUCTION}

According to the World Health Organization (WHO), approximately $10 \%$ of the global population has a permanent disability. ${ }^{1}$ In Argentina, by means of Resolution no. 1209/2010, National Program of Early Detection and Treatment of Hearing Impairment (Ministry of Public Health), it was established that hearing disability accounted for $18 \%$ of disabilities, grouped into "hearing loss" $(86.6 \%)$ and "deafness" (13.4\%). ${ }^{2}$

Although the extent of hearing loss does not predict the mode of communication, Argentine Sign Language (ASL) is the preferred communication system by many people who are deaf (DP) and / or hard of hearing. ${ }^{3}$

Two factors determine a poorly effective communication with DP: ignorance of ASL and a lack of suitable interpreters. Lip-reading, in spite of popular belief, is difficult to master. In addition, DP's mean level of reading comprehension and writing skills once they complete their education is lower than that of hearing people, which also hinders communication, even when written. ${ }^{3}$

Communication difficulties between DP and health care providers jeopardize an adequate health care provision and result in diagnosis and managements errors. ${ }^{3} \mathrm{DP}$ do not understand indications or the purpose of ancillary studies. ${ }^{4}$ This generates frustration and dissuades them from seeking care. For these reasons, DP require a professional ASL interpreter (PASLI) to achieve an effective communication during medical consultations. ${ }^{5}$ 
In Argentina, Act no. 26378 approved the Convention on the Rights of Persons with Disabilities (CRPD) and recognized the importance of access to health care so that people with disabilities are able to fully enjoy their rights. Article 9 stipulates the provision of a PASLI at no cost and without further formalities to facilitate the access of DP to public facilities, whereas Article 21 establishes the possibility of agreeing to use this mean of communication in their official interactions. ${ }^{6}$

The inclusion of ASL interpreting in health care is one of the most claimed rights by these people, because it helps them to fully participate. ${ }^{7}$ Removing participation barriers is one of the objectives proposed by the social model adopted by the CRPD regarding disability. This model considers that disability is not the problem of a person and his/her characteristics but the result of the meeting between such characteristics and the way a society is designed. ${ }^{8}$

Article 5 of the Convention on the Rights of the Child (Act no. 23849) recognized the rights and duties of parents to provide appropriate direction and guidance to their children in the exercise of their rights. In addition, Article 18 underlines the State's obligations to render appropriate assistance to parents in the performance of their child-rearing responsibilities and to safeguard the development of child-care services. ${ }^{9}$

In this regard, the absence of a professional ASL interpreting service implies the infringement of both DP's and their children's rights.

It is believed that most DP in Argentina do not have a PASLI present during their children's medical consultations. The estimation of the prevalence of DP who have a PASLI and know their right to have one would be useful to determine the current state of affairs and design strategies aimed at protecting their rights.

\section{OBJECTIVES}

- To describe the prevalence of DP who have a PASLI present at the time of their children's medical consultations in the Autonomous City of Buenos Aires (CABA) and the province of Chaco.

- To describe the prevalence of DP who know their right to access a PASLI at no cost.

\section{MATERIAL AND METHOD Design}

Descriptive, cross-sectional study with a structured, self-administered survey.

\section{Place and date}

The City of Buenos Aires and the province of Chaco, between June 1st, 2016 and April 30th, 2017.

\section{Inclusion criteria}

Deaf or hard of hearing parent who knew ASL and had, at least, one child in the pediatric age range (1 month to 18 years old), was living in the City of Buenos Aires or in the province of Chaco, and gave his/her consent to take the survey.

\section{Exclusion criteria}

DP with other disability that prevented them from completing the survey; having taken the survey before.

\section{Study outcome measures}

- Having a PASLI during their children's medical consultations.

- Knowing their right to have a PASLI.

\section{Sociodemographic outcome measures of control}

- Place of residence.

- Age of the parent completing the survey.

- Level of formal education.

- Number of children.

- Preferred method of communication.

- Use of technological resources to improve hearing.

- Being a member of an association for deaf people.

- Usual place where their children receive health care.

- The presence of a person who acted as an interpreter during their children's medical consultations.

- The relationship with the person who acted as an interpreter during their children's medical consultations.

- Whether they preferred or not the presence of a PASLI.

\section{Statistical analysis}

The studied population was described. Percentages were used for categorical outcome measures with their respective $95 \%$ confidence interval (95\% CI) and mean and standard deviation, for numerical outcome measures.

To estimate the prevalence, the absolute number of subjects with the event (having a PASLI / knowing their right) divided by the total number of observations and multiplied by 100 (95\% CI). 
Although it was not part of the objectives, the presence of factors associated with having a PASLI and / or knowing the right to have one was studied. A $\chi^{2}$ test together with the odds ratio $(\mathrm{OR})$, a t test for independent samples (categorical or continuous outcome, respectively), and a binary logistic regression analysis were used. A value of $p<0.05$ was considered significant. The IBM SPSS 20.0 software was used for the analysis.

\section{Sample size}

Based on previous observations, the prevalence of a PASLI in some countries may be up to 1 per every $10 \mathrm{DP} .{ }^{10}$ Considering this value, the sample size was calculated to estimate a prevalence of $10 \pm 5 \%$ of DP who had a PASLI during their children's medical consultations, using a 95\% confidence interval plus $10 \%$ for data loss or incomplete surveys, so 220 surveys were required (Stat Calc, Epi Info 7.1.3.10 CDC).

The CABA and the province of Chaco were selected by convenience and the survey was administered to all DP who met the inclusion criteria.

\section{Ethical aspects}

The study complied with the provisions of the Protection of Personal Information Act (no. 25326) and participants' anonymity was maintained. The survey included a header that requested participants' consent.

The approval of the Research Ethics Committee and the Teaching and Research Committee of Hospital General de Niños "Pedro de Elizalde" (Buenos Aires) and Hospital Pediátrico "Avelino Castelán" (Chaco) was obtained. The study was registered in the Health Medical Research Registry of CABA under no. CSI $144 / 16$.

\section{Procedures}

A closed, structured, and self-administered survey was used. Since this topic has been scarcely studied, there was no duly validated survey available. This survey was developed for the purpose of this study. Given that written language comprehension was different between deaf and hearing people, a deaf person adapted the survey and the questions were re-structured so that DP could understand and answer them correctly (Annex).

Based on a list of associations for deaf people and/or organizations who worked with DP and special education schools, 12 sites from the CABA and 8 sites from Chaco, including the participating hospitals, were selected by convenience (non-probability sampling).

At each selected site, all DP who met the inclusion criteria were invited to participate.

Surveys could be completed at the site where they were invited to participate (associations, schools or hospitals) or could be taken home and then completed and returned.

Although the survey was self-administered, DP could have someone else help them if they had trouble understanding it.

The instrument's reliability was pilot-tested in 20 DP. After analyzing results, minimal changes were introduced and the definite survey was obtained.

DP who met inclusion criteria were contacted through associations for deaf people, children's hospitals, special education schools, teachers, and deaf role models from the CABA and Chaco.

\section{Operational definitions:}

\section{- Deaf people}

Any person with partial or total hearing loss who, even with amplification, perceived a distorted or incomplete auditory signal; also, not hearing conversations at a normal volume. ${ }^{11,12}$

These people were also recognized as belonging to a linguistic and cultural minority community. ${ }^{13}$

\section{- Deaf role model}

A deaf person who used ASL at all times, had completed secondary education, and had the role of maintaining the deaf culture and the improvement of ASL in the educational establishment. ${ }^{14}$ Together with the hearing teacher, this person was responsible for developing a mutual learning environment and giving advice. ${ }^{15}$

\section{- PASLI}

Any person with interpreting skills from ASL into Spanish and from Spanish into ASL, who knew the sociocultural characteristics of the target communities and the code of ethics regulating his/her work, and mastered professional skills. He/she was also asked to have a degree to practice ASL interpreting. ${ }^{16}$ In the province of Chaco, a degree to practice ASL interpreting or equivalent training upon obtaining a higher-level degree in ASL with certification of at least 250 hours of ASL official interpreting workshops were accepted. ${ }^{16}$ 


\section{RESULTS}

Eleven associations, seven schools, and two hospitals were contacted until reaching the required sample size. A total of 26 DP refused to participate. Two hundred and thirty five surveys were completed; $13(5.5 \%)$ were excluded because they were incomplete, so a total of 222 surveys were analyzed. Of these participants, $53.6 \%$ (95\% CI: 47.1-60.1) lived in the CABA and $46.4 \%$ (95\% CI: 39.9-52.9), in Chaco. Table 1 describes the demographic characteristics of participants.

Of them, $77.5 \%$ had hearing children only; $13.5 \%$, deaf children only; and $8.6 \%$, both deaf and hearing children.

Also, $75.7 \%$ preferred to use ASL to communicate; $7.2 \%$, oral language; and to $17.1 \%$ of participants, it made no difference.

Besides, $74.3 \%$ did not use hearing aids or a cochlear implant; $23 \%$ used hearing aids; and $2.7 \%$ had at least one cochlear implant.

In addition, $56.8 \%$ were members of an association for deaf people.

Regarding health care services, $38.7 \%$ sought care in both public and private facilities; $37.4 \%$, only attended public facilities and $23.9 \%$, only private ones.

In relation to having someone act as an interpreter during medical consultations, $40.1 \%$ of deaf parents sometimes had an interpreter; $33.3 \%$, never had one; and $26.6 \%$, always did.

Among those who were always or sometimes accompanied by someone who acted as an interpreter $(n=148)$, in $76.6 \%$ of cases it was a relative; in $5.4 \%$, a friend; and in $1.4 \%$, a neighbor.

In relation to having a PASLI present during their children's medical consultations, $84.7 \%$ (95\% CI: 79.4-88.8) never had one and 15.3\% (95\% CI: 11.1-20.6) had one sometimes; but none of surveyed participants had a PASLI at all consultations. Among those who sometimes had a PASLI $(\mathrm{n}=34), 23$ were accompanied by a PASLI as a favor; 9 hired one specifically; and 2 had a PASLI paid by their health insurance or an association for deaf people.

Moreover, 48.6\% (95\% CI: 42.1-55.1) knew their right to have a PASLI during their children's medical consultations; while $51.4 \%$ (95\% CI: 44.857.8) were not aware of this right.

Also, 95.5\% wished to always have a PASLI during their children's medical consultation; $2.7 \%$ preferred to never have one; and $1.8 \%$ preferred to have one sometimes.

An association was observed between parents' older age and knowing the right to have a PASLI during their children's medical consultation; parents' mean age was $37.45 \pm 10.46$ years versus $32.5 \pm 9.1(\mathrm{p}<0.01)$.

The place of residence was associated with knowing the right: 77 out of 199 participants living in the CABA knew their rights compared to 31 out of 103 participants living in Chaco (OR: 4.3, 95\% CI: 2.4-7.5 ( $\mathrm{p}<0.001$ ). The other factors associated with knowing the right to have a PASLI are described in Table 2.

A binary logistic regression was done, including place of residence, age, and being a member of an association for deaf people. It showed that living in the CABA and being a member of an association were independent predictors of knowing the right to have a PASLI during medical consultations (Table 3).

In addition, not having hearing devices was related to preferring to always have a PASLI (161 out of 165 who did not have hearing device compared to 51 out of 57 who had a cochlear implant or hearing aids; OR: 4.7, 95\% CI: 1.3-17.4, $\mathrm{p}=0.03$ ).

\section{DISCUSSION}

In our study, the prevalence of DP who had a PASLI present during their children's medical

TABLE 1. Demographic data of deaf parents surveyed in both districts. $N=222$

\begin{tabular}{lc}
\hline Sex & \\
Female & $138(62.2 \%)$ \\
Male & $84(37.8 \%)$ \\
Age (average \pm standard deviation) & $34.9 \pm 10.1$ \\
Level of education & \\
Incomplete primary education & $9(4.1 \%)$ \\
Complete primary education & $46(20.7 \%)$ \\
Incomplete secondary education & $52(23.4 \%)$ \\
Complete secondary education & $84(37.8 \%)$ \\
Tertiary education & $26(11.7 \%)$ \\
University education & $5(2.3 \%)$ \\
\hline
\end{tabular}


consultations was $15.3 \%$. Less than a half knew they had a right to have one.

Although few data were available, several authors agreed on the little presence of a PASLI in health care services. ${ }^{4-17}$

The prevalence of DP who knew their right to have a PASLI during their children's medical consultations was less than a half of all surveyed participants. It was independently associated with living in the CABA and being a member of an association for deaf people. This may be due to differences in the access to information; there were more associations for deaf people in the CABA, where people gathered for the same purpose, turning them into the appropriate settings for information dissemination.

It was noted that most DP attended medical consultations with a hearing person, who attempted to act as an interpreter; two-thirds of the times, such person was a relative. In general, DP needed to attend the medical consultation with their children's grandparents. ${ }^{12}$ In other cases, children themselves acted as interpreters, without considering that they were actually too young to take on such responsibility. ${ }^{12}$ Sometimes, hearing relatives did not allow the deaf person to become actively involved in the consultation. ${ }^{4}$ Veinberg et al. pointed out the importance of taking into account that the parents had the right to know about their children's situation. In addition, these circumstances interfered with confidentiality. ${ }^{7}$

Almost all DP stated their desire to have a PASLI, even those who had hearing aids or implants.

It was observed that more than a half of deaf parents attended only public health care facilities. This would warrant the implementation of measures to ensure the right to access information on their children's health, similar to those implemented in other countries. ${ }^{1}$

Our study has potential weaknesses. The sample was selected by convenience, through the invitation of centers, schools or associations that bring DP together. However, all DP were invited to participate by each site, without specifically selecting participants. To increase the sample representativeness, two distinct populations in terms of location, demographics, and possibilities of access to health care were selected: the CABA and the province of Chaco.

In addition, there was no validated survey available for this population. Therefore, a simple survey was developed; initially it had an open structure; then it was turned into a closed, structured survey that was corrected and adapted

TABLE 2. Factors associated with knowing the right to have a professional Argentine Sign Language interpreter

\begin{tabular}{lcccc}
\hline & \multicolumn{2}{c}{ Knowing the right } & & \\
& Yes & No & RR (95\% CI) & $p$ \\
\hline Age (average \pm standard deviation) & $37.4 \pm 10.4$ & $32.5 \pm 9.1$ & & $0.01^{*}$ \\
Place of residence (CABA /Chaco) & $77 / 31$ & $42 / 72$ & $4.3(2.4-7.5)$ & $<0.001^{\text {** }}$ \\
Children (deaf/hearing or both) & $22 / 86$ & $9 / 105$ & $2.9(1.2-6.8)$ & $<0.01^{* *}$ \\
Education (inc. sec. ed./ comp. sec. ed. $^{*}$ or higher) & $44 / 64$ & $63 / 51$ & $1.8(1.1-3.1)$ & $0.04^{* *}$ \\
Being a member of an association (yes/no) & $79 / 29$ & $47 / 67$ & $3.8(2.2-6.8)$ & $<0.001^{\text {** }}$ \\
\hline
\end{tabular}

${ }^{*} \mathrm{~T}$ test for independent samples.

** $\chi^{2}$ test.

${ }^{a}$ Autonomous City of Buenos Aires.

${ }^{\mathrm{b}}$ Incomplete secondary education/complete secondary education.

OR: odds ratio; CI: confidence interval.

TABLE 3. Binary logistic regression: Predictors of knowing the right to have a professional Argentine Sign Language interpreter

\begin{tabular}{lcc}
\hline & Exp. (B) $^{\mathbf{a}}$ & 95\% $^{\text {CI for exp. (B) }}$ \\
\hline Place of residence (CABAb/Chaco) & 2.69 & $1.4-5.0$ \\
Parents' age & 0.97 & $0.9-1.0$ \\
Being a member of an association (yes/no) & 1.29 & $1.2-4.4$ \\
\hline
\end{tabular}

The outcome variable was knowing the right to have a PASLI (yes/no).

a Beta exponent.

b Autonomous City of Buenos Aires.

CI: confidence interval. 
for the comprehension of DP with the help of a suitable deaf person.

Given the scarce offer of careers to become a PASLI, the number of available interpreters is probably not enough to cover the needs of DP; this is beyond the objectives of this study. This population's access to health care information is still very limited. Future studies should describe the current situation so that actions may be implemented to warrant accessibility. ${ }^{18}$

Accepting the social model of disability is a major challenge for the medical community. In the setting of the CRPD, it is not enough to implement new regulatory measures; the key is in the ability of social sectors to put the essence of these measures into practice. ${ }^{18}$

\section{CONCLUSIONS}

In our study, the prevalence of DP who had a PASLI present during their children's medical consultations was $15.3 \%$.

Besides, $48.6 \%$ knew their right to have a PASLI during medical consultations.

The place of residence and being a member of an association for deaf people acted as independent predictors of knowing the right to have a PASLI during their children's medical consultation.

\section{Acknowledgments}

The authors would like to thank Ms. Adriana Sicilia, a deaf mother who shared her experience in the health care setting and inspired the project. Also, to the Asociación de Sordomudos de Ayuda Mutua (Association for Mutual Assistance of Deaf People, ASAM), Asociación de Artes y Señas (Association for Arts and Signs, ADAS), and Confederación Argentina de Sordos (Argentine Confederation for Deaf People, CAS) for their help administering the survey. And to Verónica Gatto Bellora for reviewing and correcting the manuscript.

\section{REFERENCES}

1. Organización Mundial de la Salud. Informe Mundial sobre la discapacidad. Malta: OMS; 2011. [Accessed on: March 2nd, 2016]. Available at: http://www.who.int/disabilities / world_report/2011/summary_es.pdf.

2. Organización Mundial de la Salud. Sordera y pérdida de la audición. 2015. [Accessed on: March 2nd, 2016]. Available at: http://www.who.int/mediacentre/factsheets / fs300/es/.

3. García García A, Zaragoza L, De Castro M, et al. Salud mental y personas sordas. Autonomía Personal 2011; (5):447.
4. Cardoso A, Rodrigues C, Bachion M. Perception of persons with severe or profound deafness. Rev Lat Am Enfermagem 2006; 14(4):553-60.

5. Sheppard K. Deaf adults and health care: Giving voice to their stories. J Am Assoc Nurse Pract 2013; 26(9):504-10.

6. Argentina. Ministerio de Justicia y Derechos humanos. LEY 26378. 2008. Apruébese la Convención sobre los Derechos delas Personas con Discapacidad y su protocolo facultativo, aprobados mediante resolución de la Asamblea General de las Naciones Unidas del 13 de diciembre de 2006. InfoLEG. Buenos Aires, Argentina, 21 de mayo de 2008. [Accessed on: March2nd, 2016]. Available at: http:/ / servicios.infoleg. gob.ar/infolegInternet/anexos / 140000-144999/141317 / norma.htm.

7. Veinberg S, Sinigaglia A. Herramientas para la comunicación. In Veinberg S. Atención pediátrica de los niños sordos, hipoacúsicos, ciegos y con baja visión: una mirada desde los derechos del niño. Buenos Aires: Fundasap; 2006. Pages45-51.

8. Cobeñas P, Fernández C, Galeazzi M, et al. Educación inclusiva y de calidad, un derecho de todos. Buenos Aires: COPIDIS-Grupo Art. 24 por la Educación Inclusiva; 2017. [Accessed on: February 5th, 2017]. Available at: http:/ / www.grupoart24.org/downloads / publicaciones / manual_educacion_inclusiva.pdf.

9. Argentina. Ley 23849. Convención sobre los Derechos del Niño. Buenos Aires, 27 de septiembre de 1990. [Accessed on: February 8th, 2017]. Available at: https: / / www.unicef. org/argentina/spanish/7.-Convencionsobrelosderechos. pdf.

10. Fundación CNSE. Acércate a la Comunidad Sorda. [Accessed on: March 6th, 2016]. Available at: http://www. fundacioncnse.org/lectura/acercate_comunidad_sorda/ acercate_comunidad_sorda_2.htm\#punto5.

11. Argentina.gob.ar beta. Ministerio de Salud. Hipoacusia. [Accessed on: March6th, 2018]. Available at: https:/ / www. argentina.gob.ar/salud/glosario/hipoacusia.

12. Veinberg S, Bonnet S. El cuidado de la salud de los niños, niñas y adolescentes sordos. Guía de recursos para profesionales de la salud. Buenos Aires: Canales; 2012.

13. Mariani M. Detección temprana de la hipoacusia y la sordera. In Veinberg S. Atención pediátrica de los niños sordos, hipacúsicos, ciegos y con baja visión: una mirada desde los derechos del niño. Buenos Aires: Fundasap; 2006.P.25.

14. Argentina. Ley 5397. Lengua de señas. Boletín Oficial, Chaco, Argentina, 4 de julio de 2005.

15. Agrelo JJ, Álvarez A, Carracedo L, et al. Trayectorias educativas integrales y configuraciones de apoyo para niños, jóvenes y adultos sordos, hipoacúsicos y para niños oyentes con trastornos del lenguaje. Buenos Aires: COPIDIS; 2011. [Accessed on: February 28th, 2018]. Available at: www.buenosaires.gob.ar/sites/gcaba/files / trayectorias_educativas_integrales.pdf.

16. Ley $\mathrm{N}^{\mathrm{o}} 6562$. Anexo a la resolución $\mathrm{N} .^{\circ} 1768$, que modifica el artículo n. ${ }^{\circ} 2$ de la Ley 6003. Boletín oficial de la Provincia del Chaco. Resistencia, 8 de septiembre de 2010; 57(9109):1. [Accessed on: March 6th, 2018]. Available at: http: / / educacion.chaco.gov.ar/app/boletin/page/56.

17. Estrada Aranda B. La vulneración de los derechos humanos de las personas sordas en México. México: Cultura Sorda; 2008. [Accessed on: November 9th, 2016]. Available at:http: / / www.cultura-sorda.org/la-vulneracion-de-losderechos-humanos-de-las-personas-sordas-en-mexico/.

18. Muñoz-Bael I, Ruiz-Cantero MT, Álvarez-Dardet C, et al. Comunidades sordas: ¿pacientes o ciudadanas? Gac Sanit 2011; 25(1):72-8. 


\section{Annex. \\ Survey on the presence of professional argentine sign language interpreters during medical consultations}

This is an anonymous survey for deaf people (both deaf and hard of hearing) who know Argentine Sign Language. DO NOT WRITE YOUR NAME.

We would like to know if deaf people have access to a professional Argentine Sign Language interpreter during their children's medical consultations Also, if they know they have a right to have a professional interpreter.

Your answer will help us to provide better health care to deaf people.

Completing this survey will take you 15 minutes. If you do not understand any question, you may ask someone else to help you.

If you do not want to complete the survey, that is OK. If you complete it, you are agreeing to participate in the survey.

If you have any doubt, please write to adriancutri@gmail.com.

Thank you for your help.

1. What province do you live in?

2. Sex (mark with an " $X$ "):

$\square$ Female.

a Male.

3. Age: years old.

4. Number of children:

Deaf:

Hearing:

5. What is your level of education? (Mark with an " $X$ ").

Incomplete primary education.

Complete primary education.

Incomplete secondary education.

Complete secondary education.

Incomplete tertiary education.

C Complete tertiary education.

Incomplete university education.

Complete university education.

6. During your children's medical consultations, how do you prefer to communicate with the physician? (Mark with an " $X$ ").

$\square$ Orally.

Sign language (ASL).

It makes no difference.

7. Do you use any of the following? (Mark with an " $X$ ").

$\square$ Hearing aids.

Cochlear implant.

$\square$ None. 
8. Are you a member of any association for deaf people? (Mark with an "X").

Y Yes.

№.

9. Where do you take your child to seek medical care? (Mark with an " $\left.X^{\prime \prime}\right)$.

口 Public hospital.

Private clinic or office.

Either.

10. During your children's medical consultations, is there someone interpreting what the physician says into ASL?

(Mark with an "X").

Always.

Sometimes.

口 Never.

11. Who explains what the physician is saying? (Mark with an " $\mathrm{X}$ ").

No one.

A friend.

A neighbor.

A relative.

An acquaintance.

A professional sign language interpreter.

12. If you have a professional ASL interpreter, how did you come to contact him/her? (Mark with an " $\mathrm{X}$ ").

He/she is at the hospital or physician's office.

You hired him/her.

You requested him/her to your health insurance.

You know him/her and he/she does it as a favor.

You never had a professional ASL interpreter.

13. Did you know deaf people have a right to always have a professional ASL interpreter during medical consultations? (Mark with an " $\mathrm{X}$ ").

a Yes.

$\square$ No.

14. Would you like to have a professional ASL interpreter during your child's medical consultations? (Mark with an " $X$ ").

always.

- Sometimes.

- Never/I do not need one. 